\title{
SLC5A1 Gene
}

National Cancer Institute

\section{Source}

National Cancer Institute. SLC5A1 Gene. NCI Thesaurus. Code C77165.

This gene is involved in carbohydrate transport. 